\title{
Assessing the Driving Forces Influencing World City Formation in Shanghai Based upon PLS-SEM Approach
}

\author{
Zeyun Li \\ Geography Section, School of Humanities, Universiti Sains Malaysia, Penang, Malaysia \\ Email: lizeyun@yahoo.com

\section{Sharifah Rohayah Sheikh Dawood} \\ Geography Section, School of Humanities, Universiti Sains Malaysia, Penang, Malaysia \\ Email: sdawood@usm.my
}

\section{Doi:10.5901/ajis.2016.v5n3s1p416}

\begin{abstract}
In the context of transnational economy, world cities have been deemed as one of the most prominent articulations pertaining into unprecedented economic globalization. Since the proliferation of foreign direct investment and economic structure restructuring, Chinese cities are characterised by the conspicuous vanguards positions embedded in world city network. In this article, the purpose is aiming to examine the major driving forces influencing world city formation in China. In practice, we attempt to choose the pre-eminent world city -Shanghai in China for elaborate case analysis. In line with the conceptual framework in terms of relationship between driving forces and world city formation in Shanghai, a total of 200 questionnaires are distributed online in order to conduct multivariate statistical analysis. Based upon world city theory, partial least squaresstructural equation modelling (PLS-SEM) using SmartPLS 3 is deployed to rigorously analyse collected data so that we can assess the subsequent measurement and structural model. Not surprisingly, this multivariable research demonstrates that the majority of selected factors significantly affect world city formation in Shanghai. According to these empirical findings, this study makes dramatic theoretical and practical contributions for the local municipal government from a new insight with reference to world city strategy in Shanghai.
\end{abstract}

Keywords: World city, Shanghai, Driving forces, Partial least squares- structural equation modelling (PLS-SEM), Multivariate analysis

\section{Introduction}

In the new millennium of transnational economy, world cities have ben spawned a much debate with reference to its borderless expansion and regional penetration. With reference to the unprecedented global -local linkage of global economy, there many intrinsic driving forces affecting world city formation in the context of globalization. Geddes (1915) was the first scholar who defined the world city in his book "Cities in Evolution". He used the city of London and Cologne in German as the holistic case studies for the world cities research. As the recognition of world cities concept, many geographers, planners, economists and sociologists conducted further research in this area, and the most dominant and prestigious contributors for world city or global city research are amongst others Peter Hall, John Friedmann and Saskia Sassen. Hall (1966) was based on the literature of Geddes; he investigated the city of New York, London, Tokyo, Paris, Moscow and some other metropolises as research subjects. According to his research, he found the pervasive characteristics and functions of world cities which differentiated from the other big cities, and these characteristics covers economic, political, finance, business, social culture, infrastructure, education and some other urban systems. These kinds of the outstanding functions cohesively give the priority of world cities in the premier nodes of global urban hierarchies in this era.

Following the seminal trajectory of previous scholars, Friedmann (1986) proposed the concept of new international division of labour, which is the underlying factor for the world city formation. In his paper "the world city hypothesis" (1986), he used seven theses to systematically analyse the world city formation mechanisms. He emphasized that financial centre is one of the functional thrusts for a world city to integrate into global economy. He argued that some big cities are experiencing the development of service sectors which replaces the manufacturing sectors. They are the "basing point" of capital, which resulted in the world cities hierarchies' formation; financial centres and company headquarters are prominent characteristics of the hierarchy. The agglomeration of financial industries in a city had the potential to incline to world city. The major world cities occupy the huge quantity of capital in the world economy, 
especially financial capital; therefore, the development of financial centres is the dominant factor to boost the world city evolution (Friedmann \& Wolff, 1982).

Sassen (1991, 1994 and 2000) had mentioned the two main forces that form the global economy, which are spatially dispersal and globally integrated. Since this trend of duality of world economy, economic activities are spatially dispersed within globalization circumstances while globally integrated industries are centralized in the world cities. She emphasized the trend that the advanced producer service industries will substitute the position of manufacturing sectors in the global economy. The internationalization, convergence and expansion of advanced producer service industries in the emerging markets will transform the economic order of the global cities. Taking together with Sassen's breakthrough, Scott (2002) concentrated on the global city-region research and mentioned that geography cannot be abolished, and global city-region formation is the trend within the world economy, especially in the developing countries. Therefore, because of China's globalizing economy and huge population threshold, it is a dominant nation for the global city-region research. Since the preliminary agenda of early scholars tend to concentrate on hierarchies and characteristics of world cities, they pay insufficient attention upon the inter-city network of world cities formation (J. V. Beaverstock, Smith, \& Taylor, 1999; P. J. Taylor, 1997). Thus, Peter Taylor and some other renowned scholars proposed the Globalization and World Cities research network (GaWC research network) in order to discover the inter-city relations of world cities. Peter J Taylor (2004) explained the process of world city network formation process; he focused on the advanced producer service firms in the globalization circumstances and world cities network. In particular this kind of world cities network contributes to development of financial/banking sector, legal firms, accounting, advertising and other producer service sectors embedded in the global connectivity among core and semi-peripheral counties.

After twentieth-first century, many researchers began to conduct the world cities research in the developing countries, especially in China. For instance, Derudder, Taylor, Witlox, and Catalano (2003), Yusuf and Wu (2002),F. L. Wu (2000), Chubarov \& Brooker (2013) and Li and Dawood (2016) concentrated on Shanghai and Beijing as the case study, they also focused on comparative study and inter-city network analysis. This kind of holistic studies of developing countries in Asia significantly contributes to the breakthrough of the world cities research trajectory. Shanghai is a pioneering economic miracle in the East Asian region, the development of Pudong new area and implementation of preferential urban restructuring strategy enable this leading world city in China to sustain its industrial development and economic growth(Wu, 1999). In response to diffusion of globalization, place promotion strategy (F. Wu, 2000), infrastructure development (Wang * \& Slack, 2004) and foreign direct investment attraction (Wei, Leung, \& Luo, 2006) facilitated by central and local government are major underlying forces to transform this metropolis to underpin a prestige status of world city integrated into global economy. The purpose of this study is aiming to investigate major driving forces affecting world city formation in the study area of Shanghai.

\section{Driving Forces Affecting World City Formation and Conceptual Framework}

There are a vast number of potential driving forces affecting world city development. Based upon seminal study of world city, Business and financial factor is deemed as one of the premier component of world city formation. These factors were rigorously discussed by some of premier scholars (Friedmann, 1986; Hall, 1966; Zeyun \& Dawood, 2016a). The major items for this construct encompass four parts. Multinational company headquarters' agglomeration are major criterion to rank the relative position (Jonathan V. Beaverstock, Smith, \& Taylor, 2000; Hymer, 1972)and control and command function (Peter J. Taylor \& Csomós, 2012; Peter J Taylor et al., 2008) of city embedded in global economy. Similarly, the global corporate network is conceptualizes as the global location strategy of business services firms (J. V. Beaverstock et al., 1999). Besides, another two fundamental items pertaining to business and financial factor are advanced producer services and international financial centre development. Specifically, the agglomeration and intensification of advanced producer services firms tend to reshape and reorganize the global urban hierarchy with respect to the global scale (Saskia Sassen, 2000). Meanwhile, the prosperity of international financial centre reinforce global urban ranking of some world cities and enlarge the polarization effect of world economy (S. Sassen, 1991).

In terms of political and institutional factor, it has been discussed many scholars (Brenner, 1998; Robinson, 2002). The most important one is international involvement and cosmopolitan reputation, cosmopolitanism and urbanization are widely acknowledged and sought to replace the circumstances of uneven development (Brenner, 1998). Market and political institutions stand out in another essential position evaluating the world city formation, notably for financial market institutions, as well as central and municipal government policies (Yusuf \& Wu, 2002). Clearly, preferential and promotional strategy has been largely debated by many scholars with respect to the world city development. Clearly , a series of aggressive promotional schemes enable majority cities to acquire a large amount of public and foreign 
investment (F. L. Wu, 2000). In addition, Ng and Hills (2003) emphasized the significance of enlightened government in promoting the democracy in global city development. In addition, Social and cultural factor is another indispensable mechanism to underpin the status of world city. International and domestic migration is major driving forces that extremely expect to enhance insights of world city formation in the face of transnational socio-cultural linkage, especially relating to skilled elite inter-urban migrations (J. V. Beaverstock, Smith, Taylor, Walker, \& Lorimer, 2000). Apart from the first item of social and cultural factor construct, the study of proliferation of education and international student admission are also occupying another relative important position in this construct (Douglass, 2000). Admittedly, the quantity of international conferences and activities incorporated into a city play a dominant role in reinforcing its world city reputation (Chubarov \& Brooker, 2013). Meanwhile, the conception of urban population size and labour forces are fairly suggested by some scholars, in particular the enlargement of population threshold of urban space, as well as its urban labour forces, will ensuring a lower possibility of labour shortage ,which is close related to urban development (Krugman, 1991).

There are extensive discussions about production and economic factor with reference to world city development (Wei et al., 2006; Zhao \& Zhang, 2007). This construct is divided into four items. Wei and Leung (2005) proposed the notion of foreign direct investment is the major underlying forces for the emergence of global city, this pattern of global inflows contribute to the spatial and economic restructuring of urban economy. On the other hand, world city is perceived as the control city of global capital derived from international division of labour (Cohen, 1981; Friedmann, 1986). Another two items in terms of manufacturing activities and production of innovation follow the trajectory of Friedmann seminal study (Friedmann, 1986; Friedmann \& Wolff, 1982).

The last construct of this article focus on the infrastructure factor construct, this construct has been noted by many scholars (Derudder \& Witlox, 2008; Keeling, 1995). Derudder and Witlox (2005) explored the inter-city linkage of transportation nodes on the world city formation. Based upon air traffic relational data, he attempted to discover the aviation node on the implications of world city formation. In terms of informational technology development and communication capacity, this concepts create a new pattern of space of flow in the network society (Castells, 1996).

Based upon previous discussion of driving forces affecting world city formation, a conceptual framework is configured, which highlights five constructs (business and financial factor, political and institutional factor, social and cultural factor, production and economic factor, infrastructure factor) as independent variables and world city formation is a dependent variable.

\section{Data and Methodology}

This research will employ quantitative method to identify relationship between major driving forces and world city formation in Shanghai. In order to examine general relationship between major constructs configured in our conceptual framework, a quantitative method of online questionnaires are distributed to local residences in shanghai. A sample framework of 200 residences in Shanghai are identified in this research, these respondents are demographic differences in terms of age, gender, job, position, working industry and hometowns. In general, based upon demographic information, respondents composited of multinational companies' and local firms' staffs and managers, government staffs, NGO staffs, and planning experts. We acquired a satisfactory respond rate with around $76 \%$ of total online distribution questionnaires. Specifically, this questionnaire constitutes of two sections. The first section includes demographic information of respondents whereas second section gives alternative selections about major driving forces influencing respondents' satisfaction towards world city development in Shanghai. A seven-point likert scale is employed in this research in order to measure the significance of measurement items associated with world city development in Shanghai. These seven scales encompass not important, less important, moderately important, neutral, important, very important and extremely important respectively based upon its dominance.

After collecting of sourced data from distributed questionnaires, a thorough data analysis is conducted using SmartPLS 3 so that we have a more deep insight on our conceptual framework between major parameters and world city formation. SmartPLS 3 is leading software based on partial least squares - structural equation modelling (PLS-SEM) to assess conceptual and theoretical relationship of collected data (Hair Jr, Hult, Ringle, \& Sarstedt, 2016). Basically PLSSEM is a fundamental multivariable statistical modelling to detect reciprocal relations between major variables of hypothetical framework. Structural model and measurement model are two basic models are tested in the PLS with regard to our hypothetical framework. In specific, structural model mainly focus on relationships between selected constructs of our research (Chin, 1998; Esposito Vinzi, Wang, Henseler, \& Chin, 2010).In contrast, measurement model attempts to discover reliability and validity between latent variables and corresponding observable variables (Hair, Ringle, \& Sarstedt, 2011; Hair Jr et al., 2016). 


\section{Results and Analysis}

In this research, there are five reflective constructs are assessed based upon PLS-SEM, which are business and financial factor, political and institutional factor, social and cultural factor, production and economic factor, infrastructure factor and world city formation. Clearly, all of the reflective constructs in this research are perceived as first order factors. The main purpose of this reflective measurement model is aiming to assess reliability and validity of our PLS-SEM. Composite reliability (CR) and average variance extracted (AVE) and two major indicators which it is most essential to assess this model scientifically (Hair et al., 2011). In terms of reliability evaluation of reflective measurement model, we should concern about indicator reliability and construct reliability.

\subsection{Measurement model analysis}

Table 1: Results of measurement model

\begin{tabular}{|c|c|c|c|c|c|}
\hline Construct & Items & Factor Loading & Composite reliability(CR) & Cronbach's Alpha & Average Variance Extracted(AVE) \\
\hline \multirow{5}{*}{ Business and financial factor } & & & 0.934 & 0.907 & 0.791 \\
\hline & Bf1 & 0.867 & & & \\
\hline & Bf2 & 0.886 & & & \\
\hline & $\mathrm{Bf3}$ & 0.935 & & & \\
\hline & Bf4 & 0.901 & & & \\
\hline \multirow[t]{5}{*}{ Political and institutional factor } & & & 0.821 & 0.768 & 0.643 \\
\hline & PI1 & 0.720 & & & \\
\hline & $\mathrm{PI} 2$ & 0.834 & & & \\
\hline & $\mathrm{PI} 3$ & 0.756 & & & \\
\hline & $\mathrm{PI} 4$ & 0.889 & & & \\
\hline \multirow[t]{5}{*}{ Social and cultural factor } & & & 0.901 & 0.912 & 0.767 \\
\hline & SC1 & 0.709 & & & \\
\hline & SC2 & 0.835 & & & \\
\hline & SC3 & 0.903 & & & \\
\hline & SC4 & 0.876 & & & \\
\hline \multirow[t]{5}{*}{ Production and economic factor } & & & 0.926 & 0.882 & 0.805 \\
\hline & PE1 & 0.892 & & & \\
\hline & PE2 & 0.913 & & & \\
\hline & PE3 & 0.865 & & & \\
\hline & PE4 & 0.839 & & & \\
\hline \multirow[t]{3}{*}{ Infrastructure factor } & & & 0.843 & 0.810 & 0.689 \\
\hline & IN1 & 0.743 & & & \\
\hline & IN2 & 0.810 & & & \\
\hline \multirow[t]{5}{*}{ World city formation } & & & 0.804 & 0.835 & 0.721 \\
\hline & WC1 & 0.769 & & & \\
\hline & WC2 & 0.886 & & & \\
\hline & WC3 & 0.801 & & & \\
\hline & WC4 & 0.823 & & & \\
\hline
\end{tabular}

As we can see from Table 1, loadings of each item with reference to respective constructs are higher than 0.7 in this research, this result of above 0.7 are considered as acceptable range of indicator reliability (Hair et al., 2011; Henseler, Ringle, \& Sinkovics; Henseler, Ringle, \& Sinkovics, 2009) In addition to indicator reliability, Construct reliability of measurement model is evaluated through Composite reliability (CR) and Cronbach's Alpha (Chin, 2010), based upon results of measurement model, all of the constructs in accordance with these two coefficients are above than 0.75 in this research, which demonstrates an acceptable construct reliability of our result. On the basis of above analysis, indicator and construct reliability of this model are relative acceptable.

In line with Table 1, validity assessment consists of convergence and discriminant validity analysis for our reflective measurement model(Esposito Vinzi et al., 2010). In order to reach an acceptable convergence validity of our measurement model, the coefficient of average variance extracted ( AVE) are intended to assess the variance of latent construct with associated items of this model, and AVE value should be above 0.5 (Hair Jr et al., 2016). Since AVE value 
of our latent variables in this research are higher than 0.643 , convergence validity is significantly accepted for our measurement model.

Apart from Table 1, discriminant validity of our research is indicated in Table 2, this validity reflects a mutual distinctions between each constructs(Chin, 1998). In order to test discriminant validity of our measurement model, most importantly, two criterions should be satisfied in our result. First, the square root of AVE value of each latent construct should be higher than any other correlative latent variables in this table. Second, each item's loading in terms of its associate latent variable should be higher than other latent variable(Hair et al., 2011). According to comparative correlation results, discriminant validity is highly acceptable for this measurement model. In conclude, based on analysis of table 1 and table 2, reflective measurement model is satisfactory with a reliable and validity results.

Table 2: Results of discriminant validity

\begin{tabular}{|l|c|c|c|c|c|c|}
\hline & $\begin{array}{c}\text { Business and } \\
\text { financial factor }\end{array}$ & $\begin{array}{c}\text { Political and } \\
\text { institutional factor }\end{array}$ & $\begin{array}{c}\text { Social and } \\
\text { cultural factor }\end{array}$ & $\begin{array}{c}\text { Production and } \\
\text { economic factor }\end{array}$ & $\begin{array}{c}\text { Infrastructure } \\
\text { factor }\end{array}$ & $\begin{array}{c}\text { World city } \\
\text { formation }\end{array}$ \\
\hline Business and financial factor & 0.869 & & & & & \\
\hline Political and institutional factor & 0.654 & 0.721 & & & & \\
\hline Social and cultural factor & 0.646 & 0.68 & 0.758 & & & \\
\hline Production and economic factor & 0.758 & 0.623 & 0.678 & 0.812 & & \\
\hline Infrastructure factor & 0.821 & 0.708 & 0.712 & 0.734 & 0.792 & \\
\hline World city formation & 0.736 & 0.689 & 0.721 & 0.648 & 0.771 & 0.824 \\
\hline
\end{tabular}

Table 3: Results of tested hypotheses

\begin{tabular}{|l|c|c|c|c|}
\hline Hypotheses & Path coefficient & $P$ value & Effect size & Supported \\
\hline Business and financial factor \& World city formation & 0.335 & $\mathrm{P}<0.01$ & 0.380 & Yes \\
\hline Political and institutional factor \& World city formation & 0.056 & $\mathrm{P}=0.145$ & 0.061 & No \\
\hline Social and cultural factor \& World city formation & 0.143 & $\mathrm{P}<0.01$ & 0.162 & Yes \\
\hline Production and economic factor \& World city formation & 0.289 & $\mathrm{P}<0.01$ & 0.245 & Yes \\
\hline Infrastructure factor \& World city formation & 0.112 & $\mathrm{P}=0.03$ & 0.105 & Yes \\
\hline
\end{tabular}

\subsection{Structural model analysis}

In the second part of this section, structural model will be addressed. As we can see from Figure 1 of our results, Rsquare assesses the endogenous construct and path coefficients gauged by structural model (Hair Jr et al., 2016). Specifically, path coefficients of our preliminary results should be significant and it is substantially associated with $\mathrm{R}$ square. The suggested threshold criterions of $R$ square are 0.67 of substantial measurement, 0.33 of moderate measurement, and 0.19 of weak measurement(Chin, 1998). According Table 3 and Figure 1, the results reflect a 0.51 of R-square in dependent variable, which is a highly satisfactory value of $R$ square. Meanwhile, we could also find the majority of path coefficients are significant with corresponding $p$ value is less than 0.05 . The only exception is political and institutional factor towards world city formation with insignificant result.

Apart from path coefficients and $\mathrm{R}$ square, effect size is another important criterion in test our hypothetical framework. Hair Jr et al. (2016) Emphasized 0.02, 0.15, 0.35 are weak, moderate and high indicators for assessing effect size of path coefficients.

Table 3 illustrate that business and financial factor towards world city formation is most substantial effect size with value of 0.380 . Similarly, the effect size of production and economic factor and social and cultural factor towards world city formation are deems as moderate value whereas infrastructure factor for world city formation is classified as weak effect size. 


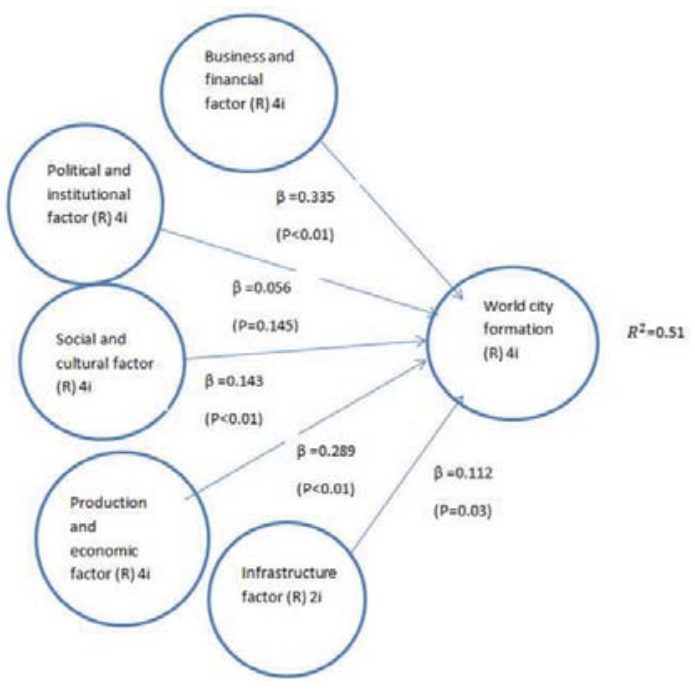

Figure 1: Results of structural model

Hence, on the basis of previous discussion about PLS-SEM results, not surprisingly, we could summarize that the measurement model is reliability and validity, and majority of latent independent variable will affect the status of dependent variable. In other words, most selected underlying driving forces have been assumed with a predictive implication on the world city formation in the study area of Shanghai.

\section{Discussion and Conclusions}

During this study, we examine major driving forces influencing world city formation in Shanghai. Based upon the application of PLS-SEM, we find four premier factors to predict our dependent variable- world city formation. Our findings suggested that, with exception to political and institutional factor, all of the remaining selected driving forces have conspicuous implications on world city formation in Shanghai. According to results of measurement model and structural model, we could demonstrate that business and financial factor are considered as most essential driving force. Following this factor, production and economic factor, as well as social and cultural factor are maintained as second tier of driving forces, which exert a moderate implication on the work city formation. Similarly, infrastructure factor is signified as least underlying driving force whereas political and institutional factor are deems as no influence on world city formation in Shanghai with insignificant result of our analysis.

On the other hand, the findings of our results are significantly consistent with previous study of world city formation. These four driving forces towards world city formation are all specifically emphasized by previous literature and research. However, institutional and political factor is indicated in previous study of world city formation where we cannot investigate the implications of this factor on the world city formation in Shanghai, thus, the inconsistent results of our finding will interpret that the institutional and political factor may not suitable for the study area of Shanghai and context of China. In addition, in conjunction with PLS-SEM, we could reach a consensus about world city formation is not only restricted to one or two factors, indeed, there are multifarious factors affected it. Hence, we should examine more factors affecting its formation. In terms of the production and economic factor, this is most critical factor influencing world city formation in Shanghai. MNC headquarter agglomeration and international financial centre play a most significant role in this construct, therefore, in our future study, we will focus on more these two items for our global urban study in the case of Shanghai.

Besides, Due to the exploration of driving forces for world city formation is a very important and valuable procedure for urban planner and city manager to conduct their world city development strategy and coordinate the available resources and capabilities to conduct this strategy smoothly, this research provides some information and framework for governor and planner to implement their world city strategy successfully. Most importantly, our finding also contributes to 
world city strategy to be applied in the context of emerging economy, especially some fast developing Asian cities. Although this research thoroughly analysis the major driving forces affecting world city formation, in some cases, it still exists some problems to be improved as this research only focus on one city case, in the future research, we will conduct comparative study of world city formation in Shanghai using PLS-SEM approach.

\section{Acknowledgements}

The authors would like to thank Universiti Sains Malaysia for providing financial assistance through USM Fellowship to conduct this research smoothly

\section{References}

Beaverstock, J. V., Smith, R. G., \& Taylor, P. J. (1999). A roster of world cities. Cities, 16(6), 445-458. doi:10.1016/s02642751(99)00042-6

Beaverstock, J. V., Smith, R. G., \& Taylor, P. J. (2000). World-City Network: A New Metageography? Annals of the Association of American Geographers, 90(1), 123-134. doi:10.1111/0004-5608.00188

Beaverstock, J. V., Smith, R. G., Taylor, P. J., Walker, D. R. F., \& Lorimer, H. (2000). Globalization and world cities: some measurement methodologies. Applied Geography, 20(1), 43-63. doi:10.1016/s0143-6228(99)00016-8

Brenner, N. (1998). Global cities, glocal states: global city formation and state territorial restructuring in contemporary Europe. Review of International Political Economy, 5(1), 1-37. doi:10.1080/096922998347633

Castells, M. (1996). Rise of the Network Society: Blackwell Publishers, Inc.

Chin, W. W. (1998). The partial least squares approach to structural equation modeling. Modern methods for business research, 295(2), 295-336.

Chin, W. W. (2010). How to write up and report PLS analyses Handbook of partial least squares (pp. 655-690): Springer Berlin Heidelberg.

Chubarov, I., \& Brooker, D. (2013). Multiple pathways to global city formation: A functional approach and review of recent evidence in China. Cities, 35, 181-189. doi:10.1016/i.cities.2013.05.008

Cohen, R. (1981). The new international division of labor, multinational corporations and urban hierarchy. In M. S. Dear, A. (Ed.), Urbanization and Urban Planning in Capitalist Society (pp. 287-315): Methuen, New York.

Derudder, B., Taylor, P. J., Witlox, F., \& Catalano, G. (2003). Hierarchical tendencies and regional patterns in the world city network: A global urban analysis of 234 cities. Regional Studies, 37(9), 875-886. doi:10.1080/0034340032000143887

Derudder, B., \& Witlox, F. (2005). An appraisal of the use of airline data in assessing the world city network: A research note on data. Urban Studies, 42(13), 2371-2388. doi:10.1080/00420980500379479

Derudder, B., \& Witlox, F. (2008). Mapping world city networks through airline flows: context, relevance, and problems. Journal of Transport Geography, 16(5), 305-312. doi:10.1016/j.jtrange0.2007.12.005

Douglass, M. (2000). Mega-urban regions and world city formation: Globalisation, the economic crisis and urban policy issues in Pacific Asia. Urban Studies, 37(12), 2315-2335. doi:10.1080/00420980020002823

Esposito Vinzi, V., Wang, H., Henseler, J., \& Chin, W. W. (2010). Handbook of Partial Least Squares : Concepts, Methods and Applications. Berlin, Heidelberg: Springer-Verlag Berlin Heidelberg.

Friedmann, J. (1986). The World City Hypothesis. Development and Change, 17(1), 69-83. doi:10.1111/j.1467-7660.1986.tb00231.x

Friedmann, J., \& Wolff, G. (1982). World city formation: an agenda for research and action. International Journal of Urban and Regional Research, 6(3), 309-344. doi:10.1111/j.1468-2427.1982.tb00384.x

Geddes, P. (1915). Cities in Evolution. London: Benn.

Hair, J. F., Ringle, C. M., \& Sarstedt, M. (2011). PLS-SEM: Indeed a Silver Bullet. Journal of Marketing Theory and Practice, 19(2), 139152. doi:10.2753/MTP1069-6679190202

Hair Jr, J. F., Hult, G. T. M., Ringle, C., \& Sarstedt, M. (2016). A primer on partial least squares structural equation modeling (PLS-SEM): Sage Publications.

Hall, P. M. (1966). The world cities. London: Weidenfeld \& Nicolson Publishing.

Henseler, J., Ringle, C. M., \& Sinkovics, R. R. (2009). The use of partial least squares path modeling in international marketing. Advances in international marketing, 20(1), 277-319.

Hymer, S. (1972). The Multinational Corporation and the Law of Uneven Development. In T. S. Hamza Alavi (Ed.), Introduction to the Sociology of "Developing Societies" (pp. 128-152): Macmillan Education UK.

Keeling, D. (1995). Transport and the world city paradigm. In P. T. Knox, P. (Ed.), World Cities in a World-System (pp. 115-131 ). Cambridge: Cambridge University Press.

Krugman, P. (1991). Increasing Returns and Economic Geography. Journal of Political Economy, 99(3), 483-499. doi:doi:10.1086/261763

Li, Z., \& Dawood, S. R. S. (2016). World City Network in China: A Network Analysis of Air Transportation Network. Modern Applied Science, 10(10), 213.

Ng, M. K., \& Hills, P. (2003). World cities or great cities? A comparative study of five Asian metropolises. Cities, 20(3), 151-165. 
doi:10.1016/s0264-2751(03)00003-9

Robinson, J. (2002). Global and world cities: A view from off the map. International Journal of Urban and Regional Research, 26(3), 531+. doi:10.1111/1468-2427.00397

Sassen, S. (1991). The Global City: Princeton University Press.

Sassen, S. (1994). Cities in a World Economy Sage, Thousand Oaks, CA.

Sassen, S. (2000). The global city: strategic site/new frontier. American studies, 41(2/3), 79-95.

Scott, A. (2002). Global city-regions: trends, theory, policy: Oxford University Press.

Taylor, P. J. (1997). Hierarchical tendencies amongst world cities: a global research proposal. Cities, 14(6), 323-332. doi:10.1016/s02642751(97)00023-1

Taylor, P. J. (2004). World city network: a global urban analysis: Psychology Press.

Taylor, P. J., \& Csomós, G. (2012). Cities as control and command centres: Analysis and interpretation. Cities, 29(6), 408-411. doi:http://dx.doi.org/10.1016/j.cities.2011.09.005

Taylor, P. J., Ni, P., Derudder, B., Hoyler, M., Huang, J., Lu, F., . . . Bassens, D. (2008). The way we were: command-and-control centres in the global space-economy on the eve of the 2008 geoeconomic transition. GaWC Research Bulletin, 289.

Wang *, J. J., \& Slack, B. (2004). Regional governance of port development in China: a case study of Shanghai International Shipping Center. Maritime Policy \& Management, 31(4), 357-373. doi:10.1080/0308883042000304467

Wei, Y. D., \& Leung, C. K. (2005). Development Zones, Foreign Investment, and Global City Formation in Shanghai*. Growth and Change, 36(1), 16-40. doi:10.1111/j.1468-2257.2005.00265.x

Wei, Y. D., Leung, C. K., \& Luo, J. (2006). Globalizing Shanghai: foreign investment and urban restructuring. Habitat International, 30(2), 231-244. doi:http://dx.doi.org/10.1016/j.habitatint.2004.02.003

Wu, F. (2000). Place promotion in Shanghai, PRC. Cities, 17(5), 349-361. doi:http://dx.doi.org/10.1016/S0264-2751(00)00031-7

Wu, F. L. (2000). The global and local dimensions of place-making: Remaking Shanghai as a world city. Urban Studies, 37(8), 13591377. doi:10.1080/00420980020080161

Wu, W. (1999). City profile: Shanghai. Cities, 16(3), 207-216. doi:http://dx.doi.org/10.1016/S0264-2751(98)00047-X

Yusuf, S., \& Wu, W. P. (2002). Pathways to a world city: Shanghai rising in an era of globalisation. Urban Studies, 39(7), $1213-1240$. doi:10.1080/00420980220135572

Zeyun, L., \& Dawood, S. R. S. (2016a). Development of the Regional Financial Centers in China: A Quantitative Study Based on the Province-level Data. Mediterranean Journal of Social Sciences, 7(3 ,S1), 374-382.

Zeyun, L., \& Dawood, S. R. S. (2016b). World Cities Formation in China: A Comparative Study of Five Pre-Eminent Cities. Mediterranean Journal of Social Sciences, 7(6), 387-396.

Zhao, S. X. B., \& Zhang, L. (2007). Foreign Direct Investment and the Formation of Global City-Regions in China. Regional Studies, 41(7), 979-994. doi:10.1080/00343400701281634 